\title{
Tertiary Overschooling in Nigeria: Theoretical Perspectives and Cases
}

\author{
Grace Koko Etuk \\ Department of Curriculum Studies and Educational Management University of Uyo \\ Akwa Ibom State, Nigeria \\ Tel: 234-80-6649-1527 E-mail: kokograce@rocketmail.com \\ Eno Gabriel Akpan \\ Department of Curriculum Studies and Educational Management University of Uyo \\ Akwa Ibom State, Nigeria \\ Tel: 234-80-2591-3010Ｅ-mail: Eny4gabe@yahoo.com
}

Etuk Nssien Etuk

Department of Curriculum Studies and Educational Management University of Uyo

Akwa Ibom State, Nigeria

Tel: 234-80-3099-5288 E-mail: e_etuk@yahoo.com

\author{
Received: April 25, 2012 \\ Accepted: May 18, 2012 \\ Online Published: June 7, 2012 \\ doi:10.5430/ijhe.v1n2p33 \\ URL: http://dx.doi.org/10.5430/ijhe.v1n2p33
}

\begin{abstract}
This paper views overschooling as conditions whereby people occupy job positions which are not optimal for their qualifications. The theoretical backings for the paper are the Human Capital, the equity and the two-factor theories of motivation and job satisfaction. Antecedents to overschooling which are mentioned include educational emphasis, the social norm and employment policy of government. Six categories of overschoolers are highlighted. Merits and demerits of overschooling and implications are proferred. The intervention strategies are suggested in eight points. The conclusion is made that stopping overschooling would reduce poverty and increase the national income leading to faster national development.
\end{abstract}

Keywords: Overschooling, Theoretical perspectives, Antecedents, Cases, Implications

\section{Introduction}

Quite unexpectedly, the building contractor came very early before we were tidy enough to entertain such a visit. His concern this time around was not with the building, which was put into use only six months earlier. Rather, his concern was with inquiring into the possibility of a better paid employment for his graduate wife, who was receiving the salary of a secondary school-leaver because she had not been promoted after putting in seven years of work. Further inquiry indicated that the man's wife was recruited to fill the position of a clerical staff when she was actually a graduate. She accepted the job offer even though she knew that it was lower than her qualification, because she did not want to miss the chance for paid employment. Since the job was in her area of specialisation, she had hoped to be up-graded after some years of service.

That woman's case is different from that of our next door neighbour in the office. Working in a tertiary educational institution, he utilized the available educational opportunity to his advantage. He was employed in the university as a clerical staff many years before we met him. By the time we were neighbours he was a master's degree holder in some discipline, but still serving as a clerical staff. He was so dissatisfied with his level of employment that he brought all his certificates to convince us of his claims. For the four years that we were neighbours, he was more absent than present at work, because he went about in search of better-paid jobs and attended several interviews to no avail. 
At home we jointly house and feed two graduates and a diploma-holder, who work in private establishments. Their compensations (wages) are so low that they are enough only for transportation. We are all happy because they can leave home to get out of trouble even though their work outcomes are not compatible with their work inputs, especially in terms of their educational qualifications and training. Cases of overschooling abound in university departments, particularly among the non-teaching staff.

From here onwards this paper will clarify the concept of overschooling as used in the paper, review selected motivational theories which are relevant to the concept of overschooling, give the background to overschooling in the Nigerian workforce; expose different perspectives of overschooling which obtain in the Nigerian workforce; state the implications of overschooling for the educational, economic and social sub sectors in Nigeria. The merits and demerits of overschooling, suggest measures towards reducing overschooling from the workforce and then conclude. We hope that this paper will enlighten readers on employment conditions among Nigerian youths.

\section{What Is Overschooling?}

Overschooling is a condition whereby somebody occupies a job position, which is lower in rank than what is expected of that individual based on his/her educational qualification and training. This suggests that there is an optimum job level for each level of education and those labelled overschoolers work below their optimum levels. The inputs into each level of education are different and the higher the educational ladder, the more the inputs both quantitatively and qualitatively. When someone who has a certain educational qualification is engaged in a job which is below his/her rank, the job level is sub-optimal for that individual. The knowledge and skill that the person acquired over the years in school are underutilized and the number of years spent in pursuing higher qualifications seem to be wasted, and also the resources spent on that educational venture. Discussions on overschooling and underschooling are in the realms of economics of education. Overschoolers are known to have high job mobility; most are usually young and single, and there are more overschooler females than males ( $\mathrm{Ng}, 2000)$.

Presently in Nigeria, neither the first-school leaving certificate (primary six), nor the Junior Secondary School (JSS) certificate qualifies holders of those certificates for employment in the civil service of Nigeria. The reason is that there is no job position in the civil service which demands holders of such certificates. This is quite unlike what obtained in the $19^{\text {th }}$ century colonized Nigeria, when even primary five leavers could be employed as clerical assistants (Fafunwa, 1974; Adeboyeje, 1992). In the 1960s independent Nigeria, first school leavers were employed as office messengers, janitors/cleaners and as attendants in agricultural farm establishments by government. Clerical positions were reserved for secondary school leavers and administrative/supervisory positions for university graduates and people with equivalent qualifications. This organizational structure obtains till today in the civil service of Nigeria. Any job placements other than this norm may be termed overschooling or underschooling, depending on the entry qualification of the job-holder and placement on the job.

Employees, who have tertiary degree certificates as entry qualifications, can rise to the highest rank in the civil service; others who hold lower qualifications may reach their bar before their retirement. An individual can come out of the bar in the civil service by going through employer-approved courses of study. If someone gets a higher qualification surreptitiously by working and studying at the same time, the employer is not bound to recognize that certificate and the person remains put in his/her former job and rank. People come out of such stalemates if there are openings in the organisation which need their qualifications. When that happens, the person concerned would not automatically move into the new opening. The person must vie and compete with other applicants within and outside the organisation.

\section{Theoretical Perspectives}

Three theories are going to be reviewed in this paper because the issue of overschooling is subsumed under them. These are the Human Capital theory by Smith, in Schultz (1971), the Equity theory by Adams (1965) and theory of motivation and job satisfaction (the two-factor theory) by Herzberg (1971). We will start with the human capital theory.

Economists originally recognized three factors of production, which were land, physical capital and labour. Land is a fixed capital, which yields rent to the owner. Fixed capitals are lasting assets. Physical capitals yield interests to their owners, but they are not as lasting as the fixed capitals. A physical capital like money is a liquid capital. Labour is an input into the production process by the human elements in the organisation. The suppliers of labour receive wages and salaries as compensations (Eze, 1983; Ebong, 2006).

The contribution of labour into the production process are in two categories - the unskilled labour and the skilled labour. The unskilled labour is pure and simple labour, while the skilled labour involves acquired human ingenuity 
and skills. The highest form of skilled labour is entrepreneurship or 'Human Capital', which is seen as the most important factor of production (Etuk, 2006, p.13; Ebong, 2006, p.15). Formal education is thought to be greatly instrumental and necessary in the production of human capitals (populations with improved productive capacities). Educated populations are regarded as productive populations.

Human resources are regarded then as the active factors of production, while machinery are the inactive factors because without the human resources, machinery alone would not produce. The skills possessed by the human elements and their motivation are imparted through education. The more years people spend in schools the more the resources put into investing in them and the more returns expected from that investment. Primary school-leavers spend six years, secondary school leavers spend 12 years and university degree holders spend a minimum of 16 years of education. The longer time people spend schooling, the more skills and motivation for work they acquire. This explains why people are placed on higher wages and salary levels when they acquire higher qualifications. It is assumed that by the time an individual completes university education, he/she can work without supervision and has more understanding than say, a secondary school-leaver. Hence, a university graduate who receives the salary of a secondary school leaver is under-paid. In other words, the person is over-schooled for the job that he/she is paid to do.

In effect, the theory of human capital is based on the belief that national growth and development are controlled by factors of production. Specialised labour and entrepreneurial skills are now counted separately from the conventional factors of production, which are land, capital and unspecialised labour. This is done with the belief that education of people is the first step towards socioeconomic development of any nation. Development cannot take place if the human capital necessary to bring about progressive change in the economy is not available (Ebong, 2006).

Human capital is the product of effective education because education gives individuals the opportunity to invest in themselves or their dependents in anticipation of better rates of return to their investments in education. Human capital, therefore, means "the acquired stock of skills, necessary to operate the physical and fixed capitals to yield increased output" (Ebong, 2006, p.17). In every economy, it is assumed that people with more education would earn higher income than people with less education who are engaged in the same type of job and supply similar services. Those who acquire higher educational qualifications had invested in education. Investment in education is counted not just in terms of money paid as fees and monies used in acquiring school supplies, which could have been used in pursuing other investments; like building houses and in buying stocks. The cost of education to an individual is also counted in terms of time spent in pursuing education, which could have been used in pursuing other ventures. In particular, the time that a person spends in school would have been beautifully utilized in working to earn money, which would have been used in pursuing other wealth-creating investments. Thirdly, the cost of education to an individual is counted in terms of lost opportunities while in school. This is termed 'opportunity cost' (Etuk, 2006, p.13; Ebong, 2006, p.15).

People make investments, with the hope of getting returns from their investments. Returns to investments depend on the nature of the asset. Rents accrue to landed assets; interests accrue to physical capital assets; wages accrue to pure and simple labour; salaries accrue to skilled labour plus personal satisfaction for entrepreneurship. Based on the theory of human capital, therefore, overschoolers are people whose returns from their investments in education are below the expected/anticipated value. They are people who are not equitably treated in terms of their work outcomes.

The likely work behaviour and attitude of overschoolers are explainable by two theories; namely, Adam's (1965) equity theory and Herzberg's (1971) two-factor theory of motivation. Adam's (1965) equity theory is a social process theory of motivation, which is based on the principle of social comparison. That theory maintains that for an individual to be intrinsically motivated, the person must be convinced that the reward/outcome from work is fair. Fairness of work outcomes are based not only on the reward that the individual gets from work, but also in what other people with comparable abilities and qualifications get from their work. Even if the individual's rewards from work is commensurate with the person's input, the person will not be satisfied if he/she knows of other jobs which would have satisfied his/her needs better with less efforts/inputs. Based on Peretomode (1991), determining the degree of equity involves comparing two ratios:

(i) the ratio of the person's work outcome and work input (Op:Ip); with

(ii) the ratio of other people's work outcome and work input (Oo:10). The comparison is expressed symbolically as:

$\frac{O p}{1 p} \quad$ Vs $\quad \frac{O o}{10}$


Any of three conditions could obtain as follows:

When $\frac{\mathrm{Op}}{1 \mathrm{p}}=\frac{\mathrm{Oo}}{1 \mathrm{o}} \quad$ there is a state of perfect equity and the person feels the outcome from work is fair
When $\frac{\mathrm{Op}}{1 \mathrm{p}}<\frac{\mathrm{Oo}}{10}$ there is a feeling of inequity and the individual feels that the reward from work is not fair
When $\frac{\mathrm{Op}}{1 \mathrm{p}}>\frac{\mathrm{Oo}}{1 \mathrm{o}}$
The middle option where $\frac{\mathrm{Op}}{1 \mathrm{p}}<\frac{\mathrm{Oo}}{10} \quad$ obtains for overschoolers.

The reward they get from work is less than what their comparable others (course or class mates) get at their different places of employment. They are bound to feel unfairly treated and dissatisfied. This may affect their work morale and productivity (Ejiogu, 1985).

Herzberg's (1971) two-factor theory of motivation is a theory which resulted from an empirical investigation of 200 accountants and engineers who represented a cross-section of workers in an industry in Pittsburg, United States of America (U.S.A.). When asked to recall specific incidents in their work experiences which either resulted in a marked improvement in their job satisfaction or a marked reduction in job satisfaction, the respondents described different activities when they felt very satisfied than when they felt dissatisfied. Through the analysis of the responses, five factors which stood out as strong determinants of job satisfaction were identified as being achievement, recognition, the work itself, responsibility and advancement on the job (promotion). Five factors which stood out as dissatisfiers were company policy and administration, supervision, salary, interpersonal relations and working conditions.

It is notable that while the satisfiers are intrinsic to the job and are highly related to the employees' work/work contents, the dissatisfiers are related to the work context/situation/environment. The dissatisfiers are termed the "hygiene factors" (Herzberg, 1971, p.326). This is analogous to the medical use of the term which means preventive factors. This implies that although the dissatisfiers do not motivate, they must be implemented to avoid/prevent job dissatisfaction. Other extrinsic rewards which are not mentioned by Herzberg (1971), but which working for an organisation is instrumental to getting them include prestige, power, security and status in society. People who fit into the category of overschoolers may not get as much of these as their comparable others.

One of the problems of Herzberg's (1971) two-factor theory is its failure to be generalizable to all populations of workers. More recent studies have indicated that the factors which are motivators or non-motivators depend on the value systems of individual workers. Workers' value systems are reflected on the different job aspects from which they derive their greatest satisfaction. Those workers who have externally- oriented value systems seek and are motivated by job values, which are related to external conditions of the work and things obtained through work. The opposite holds for workers whose value systems are internally-oriented, who are likely to be motivated by intrinsic job values, like job autonomy, responsibility and advancement on the job (Goldthorpe, 1968; Ronen, 1978; Armstong, 1993).

Studies done in Nigeria have variously and consistently identified extrinsic job factors as the motivators for the generality of Nigerian workers. These include factors like amount of money paid as salaries and other benefits, job security and retirement pension (Ejiogu, 1985; Etuk, 2002; Etuk, Etudor-Eyo and Akpanumoh, 2006). These results seem to show that Nigerian workers in general have extrinsic value systems. A possible explanation for this phenomenon may be our economic system, which is still at a very low level. Compensations for workers are not enough to raise the needs of most Nigerians above the basic physiological level.

\section{Educational, Normative and Policy Antecedents to Overschooling in Nigeria}

Formal education was introduced into Nigeria by Missionaries of British and Irish origin because until 1960, when Nigeria attained independence, Nigeria was a British colony. That being the case, the Nigerian educational system was patterned after that of Great Britain. At the primary and secondary level, where the British missionaries played the greater part, the academic curricula were complemented with the learning of skills. Irrespective of church affiliation (be it Methodist, Anglican, Presbyterian, Baptist, or Roman Catholic managed), the school time-table generally had a period a week for handwork for each grade/class of learners. In such sessions, boys were introduced to the use of local raw materials to produce household goods like baskets, mats, trays, stools and chairs. Girls were taught to use thread and needle to make home-care, personal-care and mother-care items. 
As pupils/students progressed along the educational ladder, they learnt more specialized vocational/technical skills. Boys learnt carpentry and wood-work, while girls learnt to use manual sewing machines to sew clothes, cooking local dishes and home management. Initially, the colonial (British) government did not participate in providing formal education to the citizens. While formal education started in 1842 , the colonial government came into the educational scene in 1881 , by providing a sum of money to be shared among three missionary agencies (the Methodists, the Baptists and the Roman Catholic agencies) that had schools located at Lagos, the Nigerian Capital city at that time (Fafunwa, 1974; Adeboyeje, 1992). From then on till independence in 1960, the colonial government took a keener interest in formal education by regulating and controlling educational activities through the promulgation of educational ordinances and memoranda; by basing financial grants for education on students' performances in examinations controlled by government and through the strict inspection of schools. Although the financial grants for education by the colonial government was irregular, the amount increased as time went on (Adeboyeje, 1992; Etuk, 2006).

In later years (1900s) there was such a high demand for formal education by youths in Nigeria that missionary efforts alone could not cope. The educational efforts of the Missionaries were complemented by those of natives, who set up craft centres called Commercial Schools (Adeboyeje, 1992). Government also came into providing formal education to communities in Northern Nigeria which by their religious inclination (Moslems), were averse to the introduction to formal education by Christian missionaries. Some foreign companies and organizations also opened vocational/technical centres for training their employees and would-be employees (Fafunwa, 1974; Adeboyeje, 1992). Management and financing of primary and secondary education was taken over from the missionaries by government in the 1970s, following the end of the Nigerian civil war. The educational system was restructured and elementary technology was introduced into the junior secondary school curriculum. Although it has not greatly affected employment and overschooling, government take-over of schools has been very rewarding to the Nigerian economy and development. It opened the floodgate of education for many children whose parents could not afford to pay for their education. Many secondary schools sprang up because the demand was high. Teachers became civil servants and literacy rate became higher to the present 57 per cent (Etudor-Eyo, 2012).

Tertiary education was started by the colonial government through the opening of the University College, Ibadan in 1948 (Fafunwa, 1974; Adeboyeje, 1992). The University College, Ibadan, offered purely academic type educational programmes. A technical College (the Yaba Higher Technical College) was founded at about the same time as a vocational/technical counterpart. Opening of tertiary educational institutions became more vigorously pursued at the wake of the Nigerian independence and after. Recent records credit Nigeria with 90 universities, with 28 being federally managed and financed; 35 State and 27 private universities. The polytechnics and monotechnics are 59 in number, serving a population of 150 Nigerians (Etudor-Eyo, 2012). Some of the universities are universities of technology and some of agriculture.

Despite all these efforts, formal education and training which focuses on providing vocational/technical (employment skills) do not generally capture the interests of most youths and parents in Nigeria. The reason for this is not empirically established. But, in the opinion of these writers, the people here generally associate formal education with working in offices (white collar jobs). Any form of education that deviates from this norm is suspected to lead to blue-collar employment. Preference for academic type education may also result from government policy and civil service practices in Nigeria. The Nigerian Civil Service, which happens to be the largest employer of labour up till now, used to place polytechnic graduates with Higher National Diploma (HND) at a lower salary entry point than university graduates with a first degree, which is equivalent to (HND).

After much hue and cry, both groups now enter the Civil Service at the same salary entry point. But differences still exist. The university graduate can rise to the highest rung in the Civil Service (Permanent Secretary); but the HND holder reaches the bar of his/her career earlier and cannot rise to become the Permanent Secretary of any ministry. Such considerations have put a lot of pressure on academic type education in Nigeria (Foster, 1965). Past commission reports (e.g Ashby Commission Report of 1960) (Adeboyeje, 1992) insinuated causal relationships between unemployment to lack of emphasis on vocational/technical education, and overemphasis on academic type education. Such reports have caused frequent restructuring and enrichment of the formal education curricula in Nigeria, but to no avail. Universities are highly populated while polytechnics and Colleges of Education have a dearth of students. Most university graduates come out without acquiring any specific employable skill. The few who are employed are likely to be underpaid because there are not many organizations to employ them. Government corporations and businesses have been privatized since 1999 under President Olusegun Obasanjo. Some of the private businesses have not taken off. Those that take off offer meager salaries because they are profit-oriented, unlike when those organizations were run by government. This is the crux of the matter. 


\section{Cases of Tertiary Overschoolers in Nigeria}

As can be gathered from the three case studies which formed the introduction to this paper, tertiary overschoolers are in various categories. Six categories are identified and discussed in this paper in the following paragraphs.

Those in the first category are university degree-holders and graduates from other tertiary institutions with equivalent qualifications. People in this category respond to and are selected to fill job openings, which by the civil service regulations of Nigeria are lower than their ranks. For instance, the starting salary for university graduates and people with comparable qualifications is expected to be Level 8, step whatever the employer's assessment sees fit for the prospective employee. Some graduates, out of their eagerness to get a job, may respond to a level 6 job. The person does not declare his/her higher qualification just to get that job. After a year or two, the person would file his/her higher qualifications and expect to get a raise or promotion. Management of the organisation is likely to ignore such requests, because the job the person is assigned to is meant for the rank of employees which was mentioned in the advertisement for the job. The first case in the introduction belongs in this category.

The second category of tertiary overschoolers which is identified in this paper are employees in tertiary educational institutions, who seize the opportunity of being employed in tertiary educational organizations to work and study at the same time. Management regards them as cheats if they study full time. Some tertiary educational institutions, like the University of Uyo, actually encourage their staff to study and improve their academic standings by mounting evening study programmes, sandwich programmes and continuing education programmes for the benefit of their workers.

The problem arises when these people complete their educational programmes. They expect to be upgraded and assigned to higher positions. Whether the study was done surreptitiously or done with official permission from management, the people so involved must wait until an opportunity avails itself. When the opportunity comes, it will not come in a platter of gold. There may be many people vying for the same position. Therefore, people involved compete in examinations. Those who succeed are selected to fill the vacant positions and those who are not successful return to their former ranks. The overschoolers in this category are often in a dilemma. They feel over-qualified for their jobs, but they cannot leave without an outside job offer.

The third category of tertiary overschoolers are people who genuinely obtained study-leave in their places of employment. When they return to their jobs on completion of their studies, they are nominally recognized. Although they are recognized as being graduates and what have you, they still receive their former salaries. Their salaries are not upgraded to match their new statuses. This problem is peculiar to school teachers in Nigeria.

The fourth category of tertiary overschoolers are people who are employed in organizations that have very low compensation plans for their employees. They thrive because the liberalisation of education in Nigeria has generated a lot of unemployed youths. There are little or no industries to employ them. The few industries that existed had either been shut down or privatized since the time of President Obasanjo. That was done through the advice of the World Bank/International Monetary Fund in the name of globalisation, a situation whereby public policies of world nations are bound by international regulations. Globalisation brings increased privatization, diminishing entrepreneurial roles of the state, smaller state budgets, deregulation and liberalization of state systems from former rules and controls. This is what is termed "New Public Management (NPM)" (International Labour Organisation [ILO], 1998, p.6)

Globalisation supports measures aimed at cutting costs in public administration and for strengthening the civil society. The state is expected to play new roles which consist of establishing favourable conditions for the private and non-governmental players in the society, with a high degree of self-regulation. This has resulted in a high rate of youth unemployment. Some private organisations which are not well established often underpay their workers. Graduate youths who are anxious to get paid-employment form the bulk of private-sector employees, who are underpaid. They fit into our fourth category of tertiary overschoolers. Most private schools in this part of Nigeria do not pay their staff well.

The fifth category of overschoolers are people who, for some reasons, remain in colleges and universities pursuing one degree programme after another. Such people may end up being overqualified for employment. Many years ago, a Nigerian who studied in the United States of America (U.S.A) came back with three doctorate degrees in three different disciplines. He found it so difficult to get a job that he went to the pages of a newspaper to lament his plight. The employers of labour might have thought him to be a jack-of-all-trades. It is not certain whether people who are so overschooled do it out of the desire to excel or the fear of coming out into the world of work! 
The sixth category of tertiary overschoolers are prevalent in university campuses among lecturers - from senior lecturers upwards. The practice of sending out publications of lecturers for peer review is often times frustrating when the results of the reviews are delayed for several years. The lecturers so affected may become very disgruntled and their morales may be very low.

\section{Educational, Social and Economic Implications of Overschooling in Nigeria}

The extent of overschooling which exists among members of the workforce in Nigeria casts aspersions on the adequacy of educational planning and programmes in the country. As early as 1981 Nigerians wrote their first educational policy (Federal Republic of Nigeria [FRN], 1981). There, it was very well articulated that education in Nigeria was going to be geared away from paid employment and white collar jobs for graduates. School leavers and university graduates were meant to be taught to use their brains and hands alike under good emotional state, to develop themselves and the society. Further revisions of the national policy on education stipulated that secondary school leavers and graduates from Nigerian universities would not only be self-employed, but would also be employers of labour (FRN, 2004).

Unfortunately, the issue of self employment by graduates is very illusive not to talk of graduates being employers of labour. There may be few cases no doubt, but the practice is not yet wide spread. University graduates and graduates from other systems and levels of education still flock the job market seeking paid employment. This is one of the causes of overschooling. Such a state of affairs does not augur well for the Nigerian economy and development in general.

Yet the Nigerian government subscribes to the implementation of the Millennium Development Goals (MDGs), which targets eight different areas in which world economies should excel within this Millennium. The goals include elimination of illiteracy from world populations; women development, especially their active participation in politics; improved agriculture; better care of the environment, including construction of access roads into erstwhile inaccessible communities and general development of the nation states as a whole. As early as the year 2009, when the late president Musa Yarad'ua was in power, the Nigerian government demonstrated that she was very serious about implementing the MDGs by launching an implementation programme tagged Vision 20-20-20. That programme was very popularized among the people. Vision 20-20-20 implied that by the year 2020, Nigeria would become one of the 20 most developed countries in the world, educationally, economically, politically and otherwise. Part of what would help Nigeria attain that vision is functional education; education which meets the needs of the people and the society, including providing full employment and living wages for its citizens. Such a state of affairs is likely to reduce conflicts and militancy, which youths in Nigeria are known to indulge in. The high level of overschooling in Nigeria casts doubts as to whether Vision 20-20-20 would ever be achieved. Something must be done to stop overschoooling in the Nigerian workforce and society for Vision 20-20-20 to be realised.

\section{Merits and Demerits of Tertiary Oveschooling}

Tertiary overschooling has its merits and demerits. Among those who consider overschooling meritorious are Hortog and Oosterbeek (1988), who maintain that overshooling makes the individual more productive. The reason for higher productivity may be attributed to higher brain functioning and maturity level. For example, if a university graduate is employed to fill the vacancy of a clerical staff, the graduate would have a better understanding of the issues involved; he/she is likely to command better grammar, communicate more effectively, work with a longer life experience and work without supervision. These are the considerations that make salary levels to rise higher and higher as one climbs the educational ladder. Other considerations for fixing salaries higher and higher up the educational ladder are the investments put into acquiring higher qualifications. These are time costs, financial costs and opportunity costs (lost opportunities which are spent in pursuing education instead of pursuing other investments). When all these considerations are put together, overschoolers cannot possibly be happy and contented workers. Their skills add to the level of human resource wealth and economic productivity of the state and they should equitably be rewarded. Moreover, from the point of view of the organisation, overschooling saves money which would have been used for training new staff.

Other authorities like Tsang (1987) and Ng (2000) maintain that overschooling causes lower productivity. They reason that overschoolers are likely to be less satisfied with their jobs. The productivity of a dissatisfied employee would most likely be comparatively lower. Another consequence of overschooling is the general poor attitudes of overschoolers towards relating with people in the society. A dissatisfied person is an angry person. This means that overschoolers are prone to conflicts in their relationships both at work and outside work. The more overschoolers there are in a community, the more the conflicts, which may result in violence. Most of the conflicts and violence prevalent in Nigeria today may result from unemployment and overschooling. 
Most importantly, since their incomes are low, overshoolers may not be able to save towards investment. They may end up being poor members of the society and, as such, they cannot sufficiently contribute towards economic and national development. Indeed, overschooling is Human Rights abuse and a form of modern slavery.

\section{Suggested Measures towards Reducing Overschoolers from the Nigerian Workforce}

The demerits of overschooling are overwhelmingly more than the merits. Therefore, the way forward is to explore the avenues for minimizing the frequency of overschoolers among our working and non-working populations.

(1) The Nigerian Government should revert to what it used to be by building industries, employing job seekers and paying them salaries which meet their needs, in line with the prevailing economic conditions in the country. The Nigerian government should listen to entreaties by writers like Khor (2003), who advice that developing economies are not ripe enough to be left into the hands of private individuals and organizations for management. Government should not allow the developed nations that had their independence many centuries ago, where private enterprises thrive and sustain their economies, to force globalisation policies and controls down their throats.

(2) Another way forward is the appeal to wealthy Nigerians to invest in setting up industries instead of building more and more private schools and universities. There is no point graduating more and more youths into the streets. Any wealthy Nigerian who is patriotic enough should support a public university, at least those located in their localities.

(3) Universities in Nigeria could help reduce the number of overschoolers through the kinds of programmes they mount. Universities could liaise with the few industries available to know the kinds of personnel they need. Educational programmes should be tailored towards satisfying the needs of different orgnaisations. The old academic programmes which focused on developing administrative and teaching staff should be boosted with programmes which meet present day needs. If university- industry linkages are well grounded, universities would be in the position to train staff for industrial establishments.

(4) Universities could help their overschooled staff by subjecting staff who acquire additional educational qualifications to tests and examinations appropriate for their levels of qualifications. Instead of recruiting new staff, the old staff could be upgraded to the available positions if they scale through the appraisals. Appraisal for upgrading should be an annual event and recruitment of fresh staff the last resort. This is to say that human resource planning should be part of development planning in Universities and in other employer organizations.

(5) Stringent national economic planning should be the watch-word of government and tertiary educational institutions should be made to conform with it. The number student admitted into higher educational institutions and the number released into the job market each year by tertiary institutions should be determined by the demand for those kinds of skills.

(6) Universities and colleges should mount annual seminars for students, especially the graduating class. Resource persons should be drawn from different walks of life to address participants on the available opportunities for investment and self-employment. Youths should be deschoolled (Illich, 1971) from the idea of paid employment.

(7) Government should liaise with management of universities and colleges to plan loan schemes for members of the graduating class. Those who take up the loans and excel in them should be part and parcel of the resource persons who address students on the issue of entrepreneurial skill development and self-employment. As much as possible, the youths should be made to focus on the possibility of self-employment if paid employment fails.

(8) To stem the tide of job mobility among overschoolers, private organisations in Nigeria should improve their wage structures. They should tune into the minimum wage structure of Government at any point in time. Improved wage structures could equally benefit private organisations, through experiencing less labour turn-over and becoming more stable in growth.

(9) Human Rights movements should take the issue of overschooling as one of their challenges. They should see overschooling as a form of 'modern day slavery (Note 1) of desperate job-seekers. The women liberation groups in particular should be interested in the issue of overschooling since more females than males are found to be overschoolers (Ng, 2000).

\section{Conclusion}

Overschooling arises because both public and private tertiary educational institutions in Nigeria turn out large numbers of products, who overflock the labour market. There are limited employment opportunities because government that used to be the largest employer of labour is now forbidden by globalisation policies from undertaking entrepreneurial activities. And yet private enterprises are not sufficiently grounded in Nigeria to employ 
and pay living wages to their workers. Although the employers of labour may benefit from the phenomenon of overschooling, the generality of the society suffers the ill-effects of overschooling which include poverty and dissatisfaction by members of the workforce. Workers' dissatisfaction may affect their productivity and the overall national income and gross national product. Moreover, poor workers cannot take good care of themselves and their families. They may suffer poor health and inadequate education for their children. Thus, the incidence of overschooling among members of the workforce may be recycled over and over, unless there are some intervention measures to break the trend. Such a state of affairs may help to prolong the undevelopment status of Nigeria. Minimising the number of overschoolers among our working populations needs not only the attention of government, but also the attention of higher educational institutions, private individuals and organizations, including the Human Rights groups. One way of freeing the economy for investments and national development is putting a stop to overschooling.

\section{References}

Adams, J. S. (1965). Injustices in social exchange. In: L. Beskwolz (Ed.). Advances in experimental psychology (pp.20-38). New York, NY.: Academic Press.

Adeboyeje, R. A. (1992). The early education ordinances in Nigeria (1882-1948). In: R. A. Adeboyeje (Ed.). Fundamentals of education for colleges and universities (pp.423-427). Okitipupa: ADADEP.

Armstrong, M. (1993). Managing reward systems. Buckhingham: Open University.

Ebong, J. M. (2006). Understanding economics of education. Port-Harcourt: Eagle Lithographs.

Ejiogu, A. M. (1985). Theories of job satisfaction and job performance: An overview and critique, focus on the teaching profession. Ikeja, Lagos: Joja.

Etudor-Eyo, E. U. (2012). Higher education in Nigeria. In S. U. Bassey \& U. U. Bassey (Eds.). Management of Higher Education in Nigeria (pp.1-18). Uyo: Abaam.

Etuk, G. K. (2000). Managing human resources with vocational skills for effective national development. International Journal of Educational Development, 3(1), 55-59.

Etuk, G. K. (2002). Service conditions and teaching effectiveness. Journal of Education, 2(1), 49-55.

Etuk, G. K., (2006). Education financing for colleges and universities. Uyo: Abaam.

Etuk, G. K., Etudor-Eyo, E.\& Akpanumoh, U. (2006). Teachers' conditions of service and job performance. International Journal of Education and Development, 5(1), 23-30.

Eze, A. (1983). Economics of education: The Nigerian experience. Owerri: New Africa.

Fafunwa, A. B. (1974). History of eduation in Nigeria. London: Allen and Unwin.

Federal Republic of Nigeria (1981). National policy on education Ikeja: Federal Government Press.

Federal Republic of Nigeria (2004). National policy on education. Ikeja: NERDC Press.

Foster, P. J. (1965). The vocational school fallacy in development planning. In C. A. Anderson \& M. J. Bowman (Eds.). Education and economic development (pp. 142-166). Chicago: Aldine.

Goldthorpe, J. H. (1968). The affluent workers: Industrial attitudes and behaviour. Cambridge: University of Cambridge Press.

Herzberg, F. (1971). Motivation-hygiene theory. In D. S. Pugh (Ed.). Organisational theory (pp.324-344). London: Penguin.

Hortog J. \& Oosterbeek, H. (1988). Education, allocation and earnings in the Northerlands: Overschooling? Economics of Education Review, 7(2), IXS-193, 198x.

Illich, I. (1971). Deschooling society. New York, NY.: Harper and Row.

International Labour Organisation (1988). Human resource development in the civil service in the context of structural adjustment and transition Retrieved 22/08/03 from http://www.ilo.org/pubic/enlish/dialogue/sector/techmeet/jmps98/jmpsrepl.htmff1-2.

Khor, M. (2003). Globalization and the South: Some critical issues. Ibadan: Spectrum.

Ng, Ying-Chu (2000). Overschooling and occupational change. Retrieved 10/09/2011 from: e-mail: yang@hkbu.edu.hk Google Buzz. 
Peretomode, V. F. (1991). Educational administration: Applied concepts and theoretical perspectives. Ikeja, Lagos: Joja Educational Publishers.

Ronen, S. (1978). Personal values, a basis for work motivational set and attitudes. Organisational Behaviour and Human Performance, 21(8), 80-102. http://dx.doi.org/10.1016/0030-5073(78)90041-7

Schultz, T. N. (1971). Investment in human capital. In: R. A. Wystra (Ed.) Education and economics of human capital (pp.23-41). New York, NY.: Free Press.

Tsang, M. C. (1987). The impact of overeducation on productivity: A case study of skill underutilization of the Bell companies. Economics of Education Review, 6,239-254. http://dx.doi.org/10.1016/0272-7757(87)90003-3

Note 1. Modern day slavery is a television programme aired in Cable News Network (CNN) in DSTV every 9.00pm Nigerian Time, on Tuesdays. 